\title{
Earless Diceros bicornis in the Etosha National Park, Namibia (Perissodactyla: Rhinocerotidae)
}

\author{
Ušíprostí nosorožci černí (Diceros bicornis) v Národním parku Etoša, Namibie \\ (Perissodactyla: Rhinocerotidae)
}

\section{Petr BENDA ${ }^{1,2,3}$, Jaroslav ČERVENÝ ${ }^{3}$, Seth J. EISEB ${ }^{4,5} \&$ Marcel UHRIN $^{6}$}

${ }^{1}$ Department of Zoology, National Museum (Natural History), Václavské nám. 68, CZ-115 79 Praha 1, Czech Republic; petr.benda@nm.cz

2 Department of Zoology, Faculty of Science, Charles University in Prague, Viničná 7, CZ-128 44 Praha 2, Czech Republic

${ }^{3}$ Department of Game Management and Wildlife Biology, Czech University of Life Sciences, Kamýcká 1176, CZ-165 21 Praha 6, Czech Republic

${ }^{4}$ Department of Biological Sciences, Faculty of Science, University of Namibia, Windhoek, Namibia

${ }^{5}$ National Museum of Namibia, Windhoek, Namibia

${ }^{6}$ Department of Zoology, Institute of Biology and Ecology, Faculty of Science, P. J. Šafárik University, Šrobárova 2, SK-041 54 Košice, Slovakia

received on 15 November 2020

\begin{abstract}
The syndrome of ear pinnae absence was recorded in three individuals of the black rhinoceros (Diceros bicornis) among 71 observed (4.2\%) in the Etosha National Park, Namibia, during eight visits in 2013-2020. In two cases, the syndrome comprised bilateral absence of the pinna and certain damage of the tail, while in one case, only unilateral lack of the ear pinna was recorded without any damage of the other pinna and tail.
\end{abstract}

Key words. Black rhinoceros, syndrome of ear pinnae absence, southern Africa.

The black rhinoceros, Diceros bicornis (Linnaeus, 1758) is an iconic representative of the highly endangered organisms. Its numbers in the wild dropped significantly during a few decades before 1990, just to a critical minimum enabling the survival of the species (BERGER 1994). Due to effective protection measures, the slowly recovering populations of the black rhino in the wild have recently exceeded 5,000 individuals (KNIGHT 2018); about a third of the global number of this rhino and its most viable wild populations occur in Namibia. The core area of this occurrence is in the Etosha National Park, where the number of black rhinos approaches one thousand (although the exact number is not freely published due to security reasons).

The indigenous Namibian populations of the black rhinoceros used to be considered parts of the southAfrican taxa (Groves 1967, du Toit 1987, Hillman-Smith \& Groves 1994, Emslie \& Adcock 2013), either of the nominotypical form D. b. bicornis (Linnaeus, 1758) described from the Cape of the Good Hope, or of the subspecies D. b. minor (Drummond, 1876), described from Zululand (ZukowsKY 1964). However, these populations are currently regarded to be a subspecies of its own, D. b. occidentalis (Zukowsky, 1922), 
described originally as a full species from "Kaokofeld-Kunene-Gebiet", i.e. from the north-western corner of Namibia (ZuKowsky 1922, 1964, Groves \& GrubB 2011, Moodley et al. 2017). This form, adapted to live in extreme conditions of dry shrublands and deserts, represents a unique genetic lineage (HARLEY et al. 2005, Moodery et al. 2017) and compared to other populations, it is characterised by small body size and a relatively short and broad skull (ZuKOwSKY 1964, Groves \& GRUBB 2011).

An unusual morphological phenomenon was observed in the black rhinoceroses; some individuals, mostly males, were reported to lack the ear pinna or pinnae and/or distal parts of the tail or a whole tail. This feature was perhaps first well documented from the Amboseli National Park, Kenya (GrzIMEK 1966, GugGisberg 1966, SzÉchenYi 1968). In the white rhinoceroses, Ceratotherium simum (Burchell, 1817), no similar damages were observed. De Vos (1978) reported this black rhino feature as the congenital aotus, while Hillman-Smith \& Groves (1994) as the recurring syndrome of ear pinnae absence.

GoDDARD (1969), who documented 15 such cases from East Africa, suggested a sex-linked genetic basis for this character (see also DE Vos 1978). Based on this assumption, a rhino male bearing such a damage was eliminated from the reproduction process in the Addo National Park, South Africa (DE Vos \& BRAACK 1980). On the other hand, Hitchins (1986), who reported partial or complete damages of the external ears and/or tail in 36 individuals of the black rhino in eastern South Africa, suggested a rather ecological origin of the syndrome, due to failed predator attacks. While only one of these damaged individuals had no scars in its skin and the missing pinnae were observed already in its newborn stage (moreover, without open ear apertures, thus indicating a malformation), in all remaining 35 rhinos the damaged or missing pinnae and tails were accompanied by visible scars in the skin caused likely by predators. HiTCHINS \& ANDERSON (1983) documented predator attacks on black rhino calves, presumably from the spotted hyenas, Crocuta crocuta (Erxleben, 1777), which initiated by targeted damages of ears, neck and tail.

Thus, Hitchins (1986) attributed the syndrome of ear pinnae absence to the attempted predation on black rhino calves that survived the attacks and bear the damages from predators into their adult age. Moreover, Hitchins (1986) supported his conclusion by the documentation of mother-calf escape behaviour; in the black rhino, the disturbed calf follows its mother when escaping through the bush and remains a relatively easy target for an attack from behind. On the other hand, in the white rhino which lives in the grass savannah, the disturbed calf runs ahead of its mother, which gives a good protection to the calf. This difference could explain the lack of the syndrome in the latter rhino species (Hiтchins 1986).

Some additional observations support Hitchins' (1986) assumption. Sillero-Zubiri \& GotTelli (1991) directly observed unsuccessful attacks on juvenile black rhinos by the spotted hyenas in a similar way as desribed by Hitchins \& ANDERSON (1983) as well as the earless and tailless individuals with signs of wounds from predators in Kenya. Similarly, from South Africa, Plotz \& LinkLater (2009) reported an assumed attack on the black rhino calf by the lion, Panthera leo (Linnaeus, 1758), causing injuries of the neck and anogenital region, and amputation of a large part of the tail.

As mentioned above, the syndrome of ear pinnae absence was reported from the black rhinoceros populations of East Africa (Aberdare, Amboseli, Ngorongoro, Samburu, Tsavo; GrZIMEK 1966, GodDARD 1969, Sillero-Zubiri \& Gottelli 1991) and South Africa (Hluhluwe-iMfolozi; Anderson 1966, Hitchins 1986, 1990). No reference was found on this syndrome observed in the south-western African subspecies of the black rhino, now geographically restricted to north-western Namibia.

During several visits to the Etosha National Park (31 days in total), the authors of this paper randomly observed the black rhinoceroses (see Appendix) and rarely recorded an occurrence of the earless individuals there (Table 1). Of 71 rhinos observed in various parts of the park (some $6-8 \%$ of the park rhino population - some individuals were certainly observed repeatedly), three animals (4.2\%) showed signs of the syndrome of ear pinnae absence. On 29 December 2013, an adult individual was observed in the dense Acacia shrubland north-west of the Halali Camp; this individual lacked the left pinna completely, but the right pinna and tail were without any damages (Fig. 1a, b). Two days later, on 31 December, and adult male was encountered on the road south of the Ngobib waterhole; this rhino lacked both pinnae, the ear openings had smooth edges, and the tail was shortened by ca. one third (Fig. 1c, d). On 20 October 2020, an individual of a rather small stature (perhaps a female or subadult male) was observed in a burnt shrubland area south of the Nuamses waterhole; this rhino lacked both pinnae, the ear openings had folded 



Fig. 1. The black rhinoceros (Diceros bicornis) individuals showing the syndrome of ear pinnae absence observed in the Etosha National Park (photo by P. BENDA \& M. Uhrin); a, b - NW of Halali, 29 December 2013; c, d-S of Ngobib, 31 December 2013; e, f - S of Nuamses, 20 October 2020.

Obr. 1. Jedinci nosorožce černého (Diceros bicornis) pozorovaní v Národním parku Etoša a vykazující syndrom chybějících ušních boltců (foto P. BENDA \& M. Uhrin); a, b - severozápadně od kempu Halali, 29. prosince 2013; c, d-jižně od napajedla Ngobib, 31. prosince 2013; e, f-jižně od napajedla Nuamses, 20. rŕjina 2020. 
Table 1. Numbers of observed individuals of the black rhinoceros (Diceros bicornis) in the Etosha National Park (ENP) in 2013-2020, and numbers of the recorded earless individuals;

Tab. 1. Počty pozorovaných nosorožců černých (Diceros bicornis) v Národním parku Etoša (ENP) v letech 2013-2020 a počty zaznamenaných ucha- či ušíprostých jedinců;

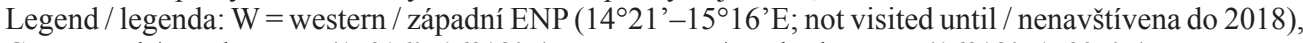
$\mathrm{C}=$ central / střední ENP $\left(15^{\circ} 16^{\prime}-16^{\circ} 12^{\prime} \mathrm{E}\right), \mathrm{E}=$ eastern / východní ENP (16 $\left.16^{\circ}-17^{\circ} 07^{\prime} \mathrm{E}\right)$

\begin{tabular}{llrrrrr}
\hline year & W & C & E & total / úhrnem & earless / bezuchý & $\%$ \\
\hline 2013 & - & 2 & 2 & 4 & 2 & 50.0 \\
2015 & - & 1 & 19 & 20 & 0 & - \\
2016 & - & 3 & 3 & 6 & 0 & - \\
2017 & - & 6 & 3 & 9 & 0 & - \\
2018 & - & 4 & 4 & 8 & 0 & - \\
2019 & 4 & 0 & 1 & 5 & 0 & - \\
2020 & 3 & 11 & 5 & 19 & 3 & 5.3 \\
\hline total / úhrnem & 7 & 27 & 37 & 71 & 3.2 \\
\hline
\end{tabular}

skin at the edges suggesting healed wounds, and the tail was shortened by ca. a half or two thirds and only a short scarred stub of the tail remained (Fig. 1e, f).

All three observations of the affected rhinos were made just in a small segment of the eastern part of the Etosha National Park where the shrubland cover seems to be more dense and compact than in the other parts. The dense vegetation perhaps supports the predators in their attacks of the rhino calves. On the other hand, the concentration of the affected rhinos in the eastern part of Etosha could be caused by a relatively high abundance of black rhinos there. As our limited data also show (see Table 1), the observations of the rhinos were most abundant in the eastern part of the park, where more than a half of the rhino encounters were made. However, this relatively high abundance is probably also caused by the presence of dense vegetation.

Anyway, the occurrence of the syndrome of ear pinnae absence in various parts of the black rhino distribution range, i.e. in populations belonging to various genetic lineages (cf. MooDLEY et al. 2017), supports Hitchins' (1986) explanation of the syndrome origin, being attributed to endured predator attacks rather than the genetic-based origin suggested previously (GODDARD 1969).

\section{SOUHRN}

Během osmi návštěv Národního parku Etoša v Namibii (celkem 31 dní v letech 2013-2020) byl u tří jedinců nosorožce černého (Diceros bicornis) z celkem 71 pozorovaných (4,2 \%; tab. 1) zaznamenán tzv. syndrom chybějících ušních boltců (obr. 1). Ve dvou prrípadech syndrom zahrnoval úplné chybění obou boltců spolu se zkrácením ocasu, $v$ jednom př́ípadě bylo zaznamenáno pouze jednostranné chybění boltce bez poškození ocasu. Tento syndrom byl původně připisován genetické odchylce a byla snaha jejich nositele mýtit z rozmnožovacího procesu populací černých nosorožců, později převládla domněnka o vzniku syndromu díky útokům predátorů na mlád’ata. Této představě také spíše odpovídají okolnosti pozorování poškozených jedinců v NP Etoša.

\section{A c know ledgements}

We thank Zdeňka Bendová, Alena Červené, Jaroslav Červený Jr., Michaela Fialová, Zuzana Kopková, Marek TURČÁNI, and Janka UhrinovÁ for their help in the field. The preparation of this contribution was supported by the Ministry of Culture (\# DKRVO 2019-2023/6.IX.b, 00023272) and by the Ministry of 
Education of the Czech Republic (\# CZ.02.1.01/0.0/0.0/16_019/0000803 financed by OP RDE). We thank Jan RoBovskÝ for his comments on earlier versions of the manuscript.

\section{REFERENCES}

ANDERSEN J. L., 1966: Tooth replacement and dentition of the black rhinoceros (Diceros bicornis Linn.). Lammergeyer, 6: 41-46.

BERGER J., 1994: Science, conservation, and black rhinos. Journal of Mammalogy, 75: 298-308.

Emslie R. H. \& Adcock K., 2013: Diceros bicornis Black rhinoceros (Browse rhinoceros, Hook-lipped rhinoceros). Pp.: 455-466. In: Kingdon J. \& Hoffmann M. (eds.): Mammals of Africa. Volume V. Carnivores, Pangolins, Equids and Rhinoceroses. Bloomsbury Publishing, London, 560 pp.

Goddard J., 1969: A note on the absence of pinae in the black rhinoceros. East African Wildlife Journal, 7: $178-180$.

Groves C., 1967: Geographic variation in the black rhinoceros Diceros bicornis (L., 1758). Zeitschrift für Säugetierkunde, 32: 267-276.

Groves C. P. \& Grubb P., 2011: Ungulate Taxonomy. The Johns Hopkins University Press, Baltimore, $\mathrm{ix}+309 \mathrm{pp}$.

Grzimek B., 1966: Kann das Spitzmaulnashorn, Diceros bicornis (Linné, 1758), die Ohren zukneifen? Säugetierkundliche Mitteilungen, 14: 39-41.

Guggisberg C. A. W., 1966: S.O.S. Rhino. A Survival Book. Andre Deutsch, London, 174 pp.

Harley E. H., Baumgarten I., Cunningham J. \& O'Ryan C., 2005: Genetic variation and population structure in remnant populations of black rhinoceros, Diceros bicornis, in Africa. Molecular Ecology, 14: $2981-2990$.

Hillman-Smith A. K. K. \& Groves C. P., 1994: Diceros bicornis. Mammalian Species, 455: 1-8.

Hitchins P. M., 1986: Earlessness in the black rhinoceroses - a warning. Pachyderm, 7: 8-10.

Hitchins P. M., 1990: Census and marking systems for black rhinoceros Diceros bicornis with special reference to the Zululand Game Reserves. Game Ranger, 1990(December): 1-12.

Hitchins P. M. \& ANDERSON J. L., 1983: Reproduction, population characteristics and management of the black rhinoceros Diceros bicornis minor in the Hluhluwe/Corridor/Umfolozi Game Reserve Complex. South African Journal of Wildlife Research, 13: 78-85.

KNIGHT M., 2018: African Rhino Specialist Group report. Pachyderm, 60: 14-39.

Moodley Y., Russo I.-R. M., Dalton D. L., Kotzé A., Muya S., Haubensak P., Bálint B., Munimanda G. K., Deimel C., Setzer A., Dicks K., Herzig-Straschil B., Kalthoff D. C., Siegismund H. R., Robovský J., O'Donoghue P. \& Bruford M. W., 2017: Extinctions, genetic erosion and conservation options for the black rhinoceros (Diceros bicornis). Scientific Reports, 7(41417): 1-16.

Plotz R. D. \& LinkLATER W. L., 2009: Black rhinoceros (Diceros bicornis) calf succumbs after lion predation attempt: imlication for conservation management. African Zoology, 44: 283-287.

Sillero-Zubiri C. \& Gottelli D., 1991: Threats to Aberdare rhinos: predation versus poaching. Pachyderm, 14: 37-38.

SZÉCHENYI Z., 1968: Denaturált Afrika (feleségemmel a fekete földrészen) [Denatured Africa (In the Black Continent with my Wife)]. Tatran Magyar Üzem, Bratislava, 378 pp (in Hungarian).

Du ToIT R., 1987: The existing basis for subspecies classification of black and white rhinos. Pachyderm, 9: $3-5$.

DE Vos V., 1978: Congenital unilateral aotus in a black rhinoceros Diceros bicornis bicornis (Linn., 1758). Journal of the South African Veterinary Association, 49: 71.

DE Vos V. \& BRAack H. H., 1980: Castration of a black rhinoceros Diceros bicornis minor. Koedoe, 23: $185-187$.

ZuKowsky L., 1922: Vorläufige Mitteilung über eine neue Art des Spitzschnauz-Nashorns aus SüdwestAfrika. Archiv für Naturgeschichte, Abteilung A, 88(7): 162-163.

Zukowsky L., 1964: Die Systematik der Gattung Diceros Gray, 1821. Zoologischen Garten (N. F.), 30: 1-178. 


\section{APPENDIX}

Observations of Diceros bicornis in the Etosha National Park in 2013-2020

The records are arranged in the chronological order; if not stated otherwise, the observation represents an adult individual.

2013: 1 ind., east of Okaukuejo, 26 December; - 1 ind., east of Okaukuejo, 27 December; - 1 ind. (syndrome of ear pinnae absence, Fig. 1a, b), north-west of Halali, 29 December; $-1 \hat{\partial}$ (syndrome of ear pinnae absence; Fig. 1c, d), south of the Ngobib waterhole, 31 December.

2015: 1 ind., 2 के, 1 + +juv., Moringa waterhole, 14 September; -2 inds. \& 1 q +juv., between Namutoni and Sprinbokfontein, 15 September; -2 inds., Moringa waterhole, 15 September; -6 inds. \& 1 + +juv., Moringa waterhole, 16 September; -1 ind., east of the Ondogab waterhole, 17 September.

2016: 2 inds., Okaukuejo waterhole, 16 August; - 1 ind., east of the Ondongab waterhole, 17 August; 1 + +juv., Moringa waterhole, 17 August; -1 ind., between Halali and Springbokfontein, 18 August.

2017: 1 ind., between Anderson's Gate and Okaukuejo, 9 May; - 3 inds. \& 1 + +juv., Okaukuejo waterhole, 9 May; - 1 ind., between Okaukuejo and Halali, 10 May; -1 $9+$ juv., Moringa waterhole, 10 May; 1 ind., near the Okerfontein waterhole, 11 May.

2018: 2 inds. \& 1 + +juv., Okaukuejo waterhole, 26 August; - 1 ind., Moringa waterhole, 27 August; 1 ind., near the Kalkheuwel waterhole, 28 August; -1 + +juv., near the Okerfontein waterhole, 28 August.

2019: $1 \hat{\partial}$, Olifantsrus waterhole, 18 May; $-1 \hat{\partial} \& 1$ o+juv., Olifantsrus waterhole, 19 May; - 1 ind., between Namutoni and Springbokfontein, 20 May.

2020: 1 ind., north-west of Halali, 8 March; - 1 ind., north-east of the Ngobib waterhole, 19 October; -1 ind. (syndrome of ear pinnae absence, Fig. 1e, f), south of the Nuamses waterhole, 20 October; 1 ind., east of the Okerfontein waterhole, 20 October; -1 ind., Goas waterhole, 20 October; -3 inds. $\& 4$ ㅇ+ +juvs., Okaukuejo waterhole, 20 October; - 1 ind., east of the Dolomietpunt waterhole, 21 October; -2 inds., Olifantsrus waterhole, 21 October. 